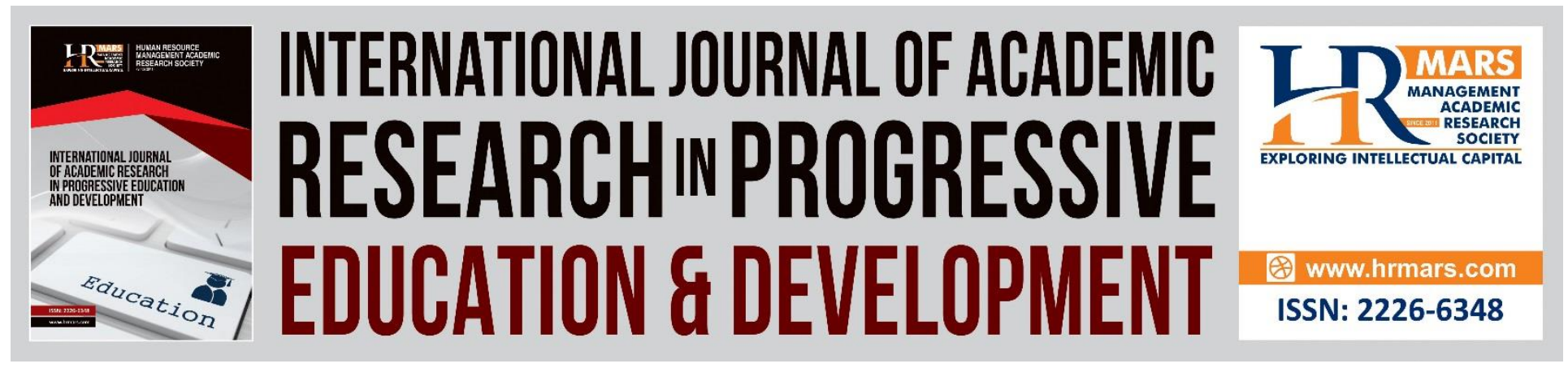

\title{
Technological Approach in Education of Musafir (Muslim Traveler) in Islam: The Study on Mobile App Mysafar
}

Wan Mohd Khairul Firdaus Wan Khairuldin, Abdul Hanis Embong, Wan Nur Izzati Wan Nor Anas

To Link this Article: http://dx.doi.org/10.6007/IJARPED/v8-i1/5499

DOI: $10.6007 /$ IJARPED/v8-i1/5499

Received: 30 Dec 2018, Revised: 21 Jan 2019, Accepted: 18 Feb 2019

Published Online: 09 March 2019

In-Text Citation: (Khairuldin, Embong, \& Anas, 2019)

To Cite this Article: Khairuldin, W. M. K. F. W., Embong, A. H., \& Anas, W. N. I. W. N. (2019). Technological Approach in Education of Musafir (Muslim Traveler) in Islam: The Study on Mobile App Mysafar. International Journal of Academic Research in Progressive Education and Development, 8(1), 40-47.

Copyright: (C) 2019 The Author(s)

Published by Human Resource Management Academic Research Society (www.hrmars.com)

This article is published under the Creative Commons Attribution (CC BY 4.0) license. Anyone may reproduce, distribute, translate and create derivative works of this article (for both commercial and non-commercial purposes), subject to full attribution to the original publication and authors. The full terms of this license may be seen

at: http://creativecommons.org/licences/by/4.0/legalcode

Vol. 8, No. 1, 2019, Pg. 40 - 47

http://hrmars.com/index.php/pages/detail/IJARPED

JOURNAL HOMEPAGE

Full Terms \& Conditions of access and use can be found at http://hrmars.com/index.php/pages/detail/publication-ethics 


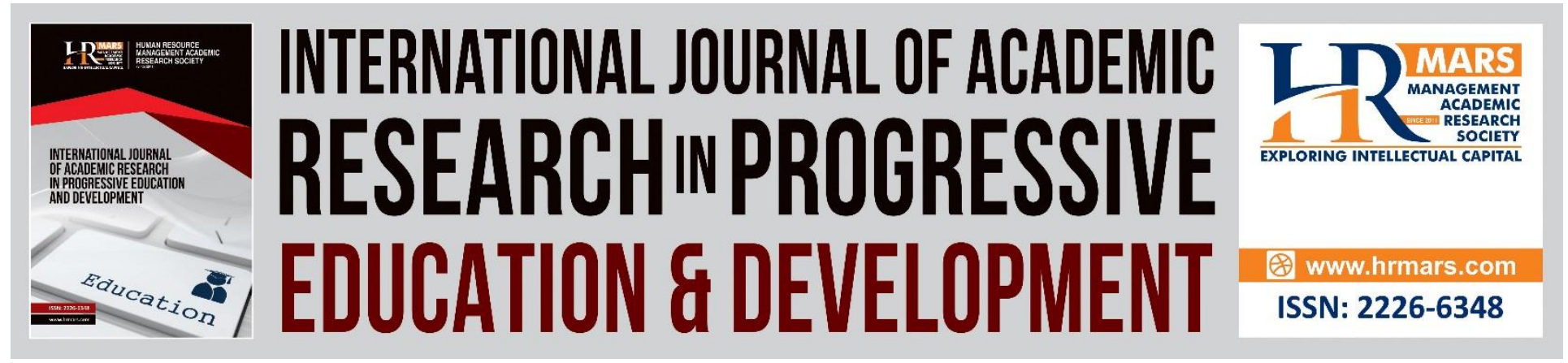

\title{
Technological Approach in Education of Musafir (Muslim Traveler) in Islam: The Study on Mobile App Mysafar
}

\author{
Wan Mohd Khairul Firdaus Wan Khairuldin \\ Research Institute for Islamic Product \& Civilization (INSPIRE), Universiti Sultan Zainal Abidin, \\ MALAYSIA \\ Abdul Hanis Embong \\ Centre for Fundamental and Liberal Education, Universiti Malaysia Terengganu, MALAYSIA
}

\author{
Wan Nur Izzati Wan Nor Anas \\ Academy of Islamic Studies, University of Malaya, MALAYSIA
}

\begin{abstract}
Nowadays, travel that commonly known in Islam as a musafir is a phenomenon for most Muslims in the world. At the same time, Islam itself encourages muslims travelling to see the greatness of God's creation. In fact, travelers is also gain knowledge and goodness from the journey. Therefore, Islam has special guidelines in traveling. However, most Muslims are sometimes confused about the implementation. With technological advances, some of these things can be solved. This study uses the documentation method as a method of data collection and content analysis method as a method of data analysis. The findings suggest that travel is the things that are urged by Islam because of its benefits; physically and spiritually. The technological approach is also seen to assist many of the problems in the understanding. This includes determining the distance and duration of the traveler. Therefore, it is recommended to develop appropriate applications to facilitate Muslim travelers in the future.
\end{abstract}

Keywords: Musafir, Technology, Mysafar, Education

\section{INTRODUCTION}

Tourism is a new trend in the world community today. Tourism is a lifestyle practiced by most people in the world. The World Tourism Organization (UNWTO) (2015) has estimated that there are 1.133 billion international tourists worldwide in 2014. This is an increase of $4.3 \%$ compared to 1.087 billion in 2013. This shows a considerable figure in world tourism. 
Tourism not only involves foreign countries, but also involves Islamic countries and Islamic tourism. The four major Muslim countries in the world have become the tourist center for Muslim and non-Muslim tourists. The country is Egypt, Morocco, Malaysia and Turkey who successfully promote their countries for Islamic tourism. In 2012 only, his four countries receive beyond 86 million international tourist arrivals (Nurrachmi, 2017). This shows that the Islamic tourism sector has also begun to get a lot of attention today (Abdullah \& Mukhtar, 2014).

This increase in Islamic tourism also involves the concept of traveling to Muslims. Islam recognizes travelers who travel to their destination. As such, Islam has set some specific rukhsah (concession) concepts that can be applied by Muslim tourists. Among of concession are the prayers of jama' qasar, the breaking of fast and so on. However, the problem of understanding this concept often has problems among Muslims. In fact, sometimes some things need to be scientifically explained that can strengthen education and the implementation of worship to tourists. Therefore, education related to Islamic tourism should be carried out effectively with the use of current technology facilities. For that matter, the the scientific method should be used. With the absence of specific app before, a convenient app needs to be built. Therefore, MySafar is a form of app that makes it easy for users to get scientifically answered practices while traveling.

\section{METHODOLOGY}

Data collection for this study uses document analysis method or library research method. The data collected from classical and contemporary books. The collected data analyzed using content analysis method. Content analysis is used to examine and explain the interpretation contained in the document. According to Krippendorff (2004), content analysis is a research technique by making systematic and objective conclusions through documented data. It coincides with the data collected from certain documents involving works of writing. In the case of this study, content analysis is to get a clearer picture of the technological approach in Islamic Travelling education.

\section{DISSCUSSION}

\section{Travel and Tourism in Islam}

The concept of Islamic tourism to date has a wide range of definitions based on diverse concepts of understanding (Khairuldin et al., 2018). Generally, adventure and tourism in Islam is an activity that has its own objectives, especially the ultimate goal of every individual. The goal is physically, socially and spiritually. This is clearly different from western tourism that focuses solely on physical aspects (Khairuldin, 2016). Islam sees tourism as a form of appreciation about the creation of the earth by God in seeking His pleasure. Therefore, there are various principles that Islam has put in order to achieve that (Kadir Din, 1989).

Some scholar of Islamic tourism refer Muslim as the travelers who travel to certain destinations for religious purposes only (Zamani-Farahani \& Henderson, 2010). However, this concept is clearly inaccurate if it is discussed based on the terms mentioned in the Qur'an. Hence, generally Islamic tourism is not limited to religious tourism or special worship alone. Islam also gives 
freedom to its people to do all kinds of tourism. However, such travel does not conflict with values set by Islam (Shakiri, 2006).

Among the closest terms to the word travel is Islam are the musafir or safar. The word traveler comes from the Arabic verb, safara. Words are interpreted with a variety of meanings such as going, walking, wandering or setting distance. While the word traveler is addressed to the person who travels to a destination that is determined and has a purpose. This is because, if they do not meet these requirements, they are not referred to as travelers (Wahbah al-Zuhaili, 1997).

For those meet the requirements, there is a certain concession allowed. It was discussed in figh books as people who go out of their homes to a place that meets a certain distance of the traveler. As a result, the perpetrator is required to shorten the prayer or breaking fasting on ramadhan (al-Qahtani, 2007).

\section{TECHNOLOGICAL APPROACH IN EDUCATION OF MUSAFIR}

The learning within mobile devices or better known as M-Learning has long been growing rapidly overseas such as Europe and the United States (Shuib, 2009). In Malaysia, the term m-Learning has been introduced in the general public especially in the curriculum of higher education (Siraj, 2004; Kamal \& Tasir, 2008). According to Kulkulska-Hulme and Traxler (2005), M-Learning is one of the new concepts in the learning process that emphasizes the use of mobile devices without being bound by time and place. This statement is supported by Quinn (2002) that defines mLearning as a learning process using mobile devices like Palms, PDA (Personal Digital Assistant), computers, mobile phones and so on.

According to Seong (2006), learning through $\mathrm{m}$-Learning has provided various alternatives and facilities in social interaction. For example, cellphone usage is no longer limited to receiving and making calls. In fact, mobile phones also have the convenience of sending and receiving email, short messaging (SMS), multimedia messaging services (MMS) and equipped with facilities as a medium in learning.

Rahman et al. (2015) found that there was a positive impact on the use of technology on religiousrelated learning. This study was conducted on Islamic education teachers. They provide a positive response to the use of electronic technology in the learning process. This shows that the use of technology in the learning process is appropriate especially for the field of Islamic studies.

Furthermore, there are several studies on the use of e-Learning technology in the study of another Islamic knowledge, especially the Quran. Among them are the study by Saleh \& Shukor (2004), Rahim (2008) and Selamat et al. (2015). Study by. Rahim (2008) is in line with the study of Selamat et al. (2015). They believe the development of information technology can be used to enhance the system of memorization in the process of learning and teaching among the Quranic memorabilia. Rahim (2008) adds that the factors that can be identified become the source of weakness in the teaching and learning method of tahfiz when the teacher still maintains the traditional method in the process of teaching and learning the Quran. This statement was also supported by Saleh and Shukor (2004). 
To facilitate the traveler in their journey, a smartphone application is recommended. The application is named as MySafar. MySafar is a technology innovation using smartphone-based software to figh travelers. It functions as a measuring distance of the remembrance and the duration of the settlement of a Muslim who wants to travel to a destination. This software is important to a Muslim to determine the need to perform prayers when traveling or upon arrival to the destination. To adapt to the Muslim landscape of Malaysia, this software is a prototype built on fiqh Syafie sect. The production of the MySafar prototype is expected to resolve confusion among the Muslim community and facilitate them to plan the interpretation.

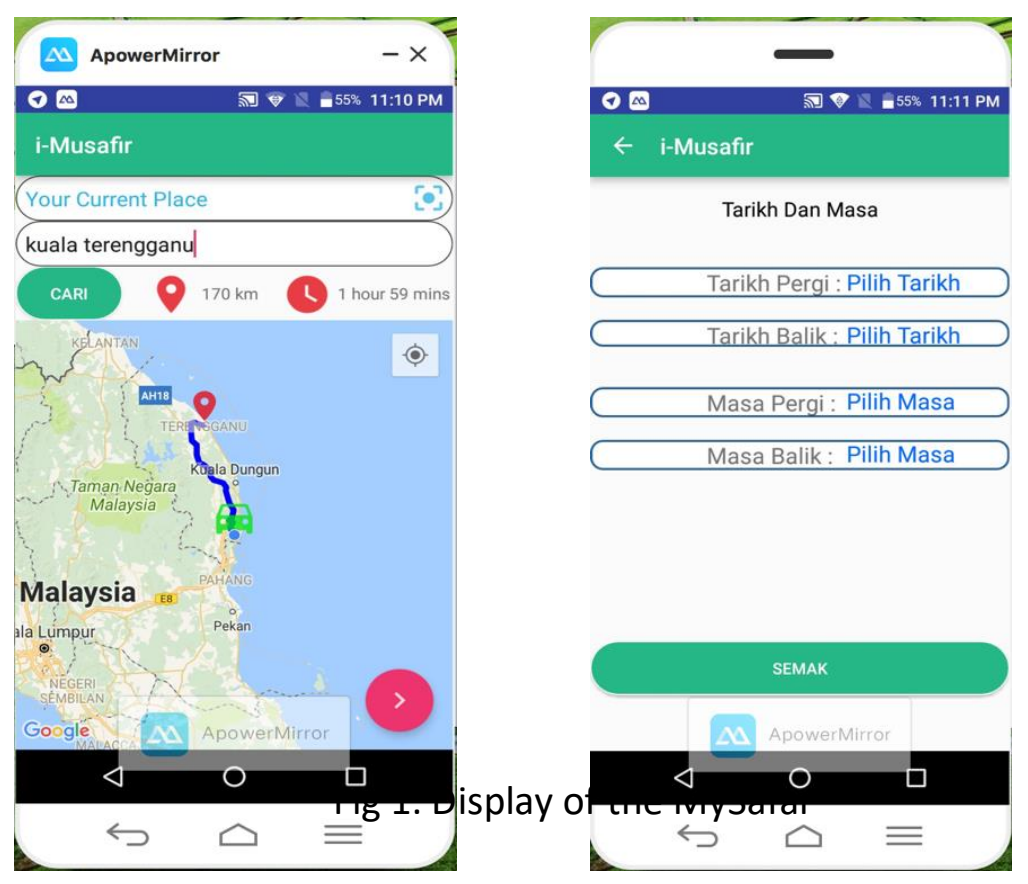




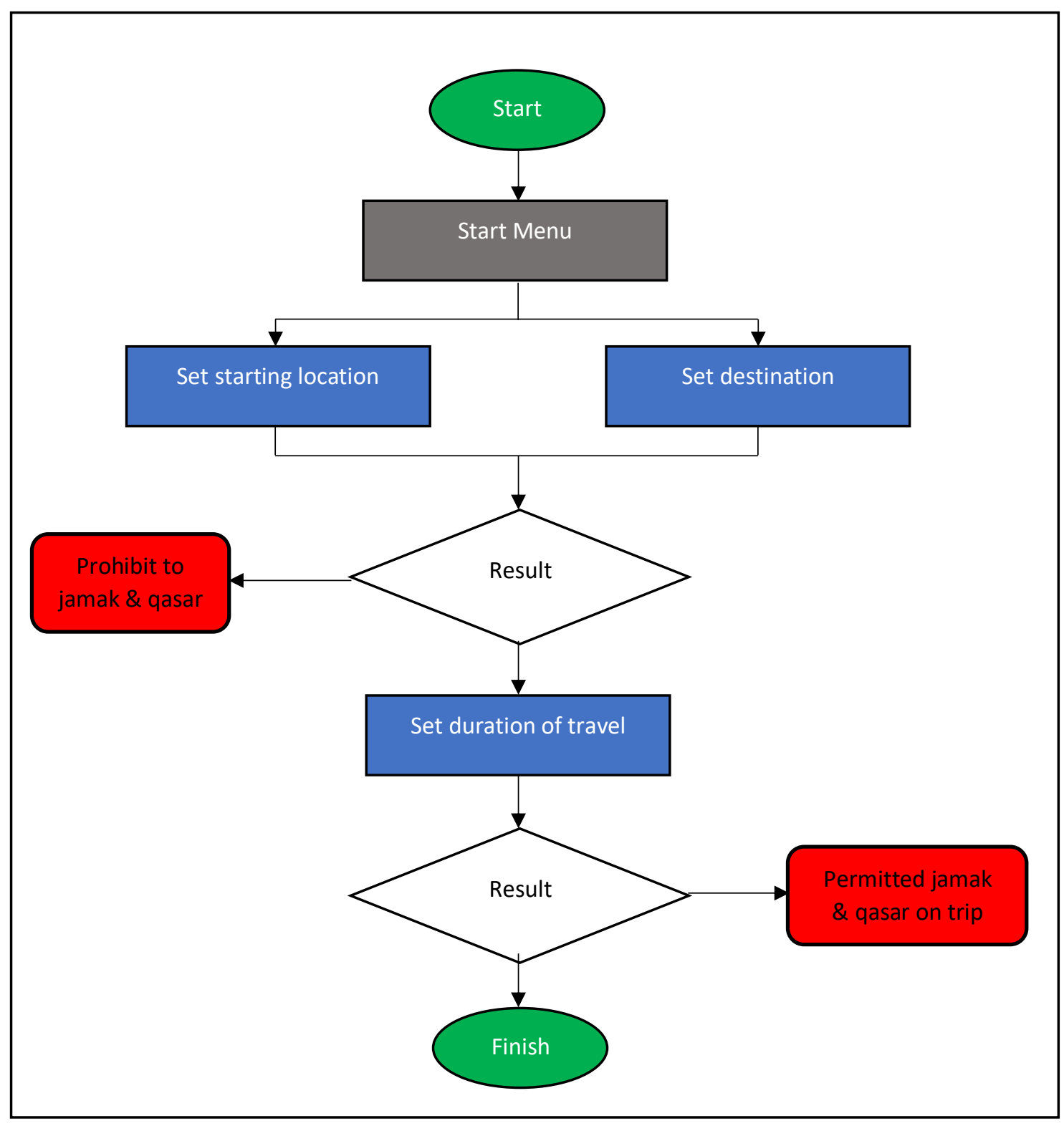

Fig 2. Flowchart of MySafar

\section{CONCLUSION}

In conclusion, the traveler is a practice that is strongly encouraged by Islam. As such, Islam has set some facilities and concessions to travelers. To facilitate education and guide to travelers, a smartphone app is built on the basis of requirements. This is a prelude that all Muslim travelers can use.

Besides that, MySafar allows travelers to calculate the same journey is related to distance or length of time. In addition, the app can also resolve the confusion of the community towards the implementation of worship while traveling in Islam. 
International Journal of Academic Research in Progressive Education and Development

Vol. 8, No. 1, 2019, E-ISSN: 2226-6348 @ 2019 HRMARS

\section{ACKNOWLEDGEMENT}

Special appreciations to the Research Management, Innovation \& Commercialization (RMIC), University of Sultan Zainal Abidin (UniSZA) for sponsoring the project.

\section{REFERENCES}

Abdullah, N.F. \& Mukhtar, M. (2014). Konsep Pelancongan Islam: Satu Pengamatan. Proceeding Seminar Kebangsaan Penyelidikan dan. Pendidikan Islam Politeknik 2014.

Al-Qahtani. (2007). Hisn al-muslim min adhkar al-kitab wa al-sunnah. Beirut: Dar al-Fikr,

Al-Zuhayli, W. (2001). Fiqh al-Islami wa-Adilatuhu. Beirut: Dar al-Fikr.

International Journal of Academic Research in Progressive Education and Development, 7(4), 295-302.

Kamal, S.A.S.Y. \& Tasir, Z. (2008). ‘Pembelajaran Masa Depan- Mobile Learning (M-Learning) di Malaysia' dalam Seminar Penyelidikan Pendidikan Pasca ljazah 2008, 25-27 November 2008, Universiti Teknologi Malaysia.

Khairuldin, W. M. K. F. W. (2018). Fatwa Role in Education and Legal Dispute in Malaysia.

Khairuldin, W. M. K. F. W., Anas, W. N. I. W. N., \& Embong, A. H. (2018). The Binding of Laws to Personal Opinion of Muftis in Malaysia. International Journal of Academic Research in Business and Social Sciences, 8(11), 522-529.

Khairuldin, W. M. K. F. W., Anas, W. N. I. W. N., \& Embong, A. H. (2018). Fatwa as a Disseminator of Islamic Laws among Community of Malaysia. International Journal of Academic Research in Business and Social Sciences, 8(11), 516-521.

Khairuldin, W. M. K. F. W., Embong, A. H., Anas, W.N.I.W.N., Mohd, H. \& Ismail, D. (2018). The Application of Technology in the Dissemination of Fatwas: A Study on Religious Institutions in Malaysia, International Journal of Civil Engineering and Technology, 9(7), 2018, pp. 15901596.

Khairuldin, W.M.K.F.W. (2010), Metode Fatwa Sheikh 'Ali Jumaa'ah dalam Kitab al-Kalim alTayyib- Fatawa 'Asriyyah. Unpublished Master Thesis. University of Malaya.

Khairuldin, W.M.K.F.W. (2016), Konsep Fatwa dalam Islam. Kuala Terengganu: Penerbit Universiti Sultan Zainal Abidin.

Khairuldin, W.M.K.F.W., Ismail, D., Anas, W.N.I.W.N., Ibrahim, I., \& Fauzi, N. (2016). Freedom of Speeches by Mufti According to Islam: Implication to Fatwa in Malaysia. International Journal of Academic Research in Business and Social Sciences. 6 (12). Pp 141-151.

Krippendorff, K. (2004). An introduction to its methodology. Thousand Oaks, CA: Sage.

Mohamad Marzuqi Abd. Rahim. (2008). Pengajaran Mata Pelajaran Hafazan al-Quran: Suatu Kajian Maahah Tahfiz al-Quran Zon Tengah. Master's thesis. Fakulti Sains Kognitif dan Pembangunan Manusia: Universiti Pendidikan Sultan Idris.

Nurrachmi, R. (2017). Islamic Tourism:Factors that Influence Muslim Tourists and How to Promote Tourism in OIC Countries, Intra-Trade in OIC. Jeddah: Islamic Development Bank.

Quinn, C. (2002). MLearning: mobile, wireless, in you pocket learning. Linezine. Access form http://www.linezine.com/2.1/features on 4th March 2019.

Saleh, N.S.N. \& Shukor, S.A. (2004). E-Learning in Islamic Studies: Possibilities and Challanges in Malaysia. dalam Prosiding Islam: Past, Present and Future International Seminar on Islamic Thoughts. UKM: Jabatan Usuluddin dan Falsafah. 
Selamat, M.Z. (2015). Penggunaan Teknologi Semasa Dalam Menghafal al-Quran. Koleksi Persidangan dalam Memasyarakatkan Quran, Mensejahterakan Ummah. Kuala Lumpur: Universiti Malaya. 184-193.

Shakiri, A.A. (2008) Islamic Tourism Prospect For World Peace. TCPH Limited.

Siraj, S. (2004). 'Pembelajaran Mobile dalam Kurikulum Masa Depan' dalam Jurnal Masalah Pendidikan, Issues in Education, 27. Pp. 129-141.

Yasin, M.F.M., Embong, A.H., Khairuldin, W.M.K.F.W., Rahim, R.S.A., Abdullah, A., Said, S. \& Mutalib, N.A. (2018). Contributions of Technology Towards Development Of Qur'anic Tajweed Knowledge, International Journal of Civil Engineering and Technology, 9(6), 2018, pp. 1340-1352

Zamani-Farahani, H., \& Henderson, J. C. (2010). Islamic tourism and managing tourism development in Islamic societies: The cases of Iran and Saudi Arabia. International Journal of Tourism Research, 12 (1), $79-89$. 